ISSN 1392-3196 / e-ISSN 2335-8947

Zemdirbyste-Agriculture, vol. 104, No. 2 (2017), p. 99-106

DOI 10.13080/z-a.2017.104.013

\title{
Artemisia dubia growth, yield and biomass characteristics for combustion
}

\author{
Žydrè KADŽIULIENE' ${ }^{1}$, Vita TILVIKIENE $\dot{1}^{1}$, Inga LIAUDANSKIENE $\dot{1}^{1}$, Lina POCIENE்], \\ Živile ČERNIAUSKIENE ${ }^{2}$, Egidijus ZVICEVICIUS ${ }^{2}$, Algirdas RAILA ${ }^{2}$ \\ ${ }^{1}$ Institute of Agriculture, Lithuanian Research Centre for Agriculture and Forestry \\ Instituto 1, Akademija, Kèdainiai distr., Lithuania \\ E-mail: zkadziul@1zi.lt \\ ${ }^{2}$ Aleksandras Stulginskis University \\ Studentų 11, Kaunas distr., Lithuania
}

\begin{abstract}
In recent years, there has been increasing interest in the use of agricultural biomass for energy purpose in many northern countries. This has created demand for novel, high biomass yielding, specific quality crops for sustainable use. The aim of the current study was to examine Artemisia dubia Wall. for biomass yield and biomass characteristics important for combustion in the temperate climate conditions. The crops were grown on an EndocalcariEpihypogleyic Cambisol (CMg-p-w-can) without fertilization and with mineral nitrogen fertilization at 90 and $170 \mathrm{~kg} \mathrm{ha}^{-1} \mathrm{~N}$ rates. Nitrogen fertilization slightly increased plant height and accumulation of biomass. Moisture content in the biomass of swards applied with a higher rate of mineral $\mathrm{N}$ decreased more slowly compared with the lower rate. Biomass annual yield in the second and third years ranged from 15.8 to $17.1 \mathrm{t} \mathrm{ha}^{-1}$; however, significant effect of nitrogen fertilization was not observed. Nitrogen fertilization had a significant influence on $\mathrm{N}$ content and lignin in the biomass. The variation of values of the elements relevant for combustion (carbon and sulphur) in the biomass was negligibly influenced by nitrogen fertilization. The relatively low ash content and heating value, amounting to $8.5 \mathrm{MJ} \mathrm{kg}^{-1}$ achieved even without nitrogen fertilization, makes $A$. dubia a promising energy crop in the northern part of the temperate climate zone. More studies and analyses on A. dubia are needed to ascertain the fertilization effect on biomass yield, biomass quality and biomass properties for combustion in senescent plants.
\end{abstract}

Key words: ash, energy crops, fibre components, heating value, nitrogen fertilization.

\section{Introduction}

The development of bio-based economy is increasingly focusing on biomass supply and conversion to energy. On a global scale, there has been observed a significant increase in the demand of biomass supply in conversion chain (Scarlat et al., 2015). The composition of biomass as feedstock for combustion needs to be harmonized with technological processes, considering the whole chain sustainability (Y1lmaz, Selim, 2013; Seay, Badurdeen, 2014).

The use of biomass and conversion to energy should be cost-effective, reliable and contribute to the mutual benefit of the biomass supplier and processor. Combustion is prevalent conversion pathway for the lignocellulosic biomass (Prochnow et al., 2009; Tonn et al., 2010) and for energy; however, biomass has some limitation (Williams et al., 2012). High biomass productivity and suitable quality are needed for any energy purpose (Searle, Malins, 2014) and there always exist requirements for sustainably produced biomass (Robbins et al., 2012). Different species of energy crops
(Laurent et al., 2015) or low input high diversity biomass (Van Meerbeek et al., 2015; Corton et al., 2016) or wild plant mixtures (Von Cossel, Lewandowski, 2016) have been identified as biomass feedstocks for bioenergy. Naturally, the choice of plant species varies depending on the conversion pathway. Reed canary grass is usually referred to as a potential crop for combustion (Jasinskas et al., 2008; Heinsoo et al., 2011; Lord, 2015), while for other energy purposes more traditional grasses have been identified (Tilvikiene et al., 2016). Perennial grasses show considerable potential for bioenergy production; however, these crops can vary in regional adaptability and yield in different environments and year to year, and optimizing the nutrient efficiency and the potential for suitable conversion to energy are important components in bioenergy pathway (Palmer et al., 2014). Some energy crops are criticized (Naik et al., 2010; Pedroli et al., 2013) because their biomass production requires highinputs of fertilizers and pesticides, and this poses a threat to the environment and food security (Tilman et al.,

Please use the following format when citing the article:

Kadžiulienė Ž., Tilvikienė V., Liaudanskienè I.,PocienėL., ČerniauskienėŽ., ZviceviciusE., RailaA. 2017. Artemisia dubia growth, yield and biomass characteristics for combustion. Zemdirbyste-Agriculture, 104 (2): 99-106 DOI 10.13080/z-a.2017.104.013 
2009; Dauber et al., 2010). On the other hand integration of bioenergy systems into the agricultural landscape can contribute positively to increased $\mathrm{N}$ recirculation and to mitigation of environmental impacts associated with $\mathrm{N}$ losses, while at the same time providing renewable energy for society (Skenhall et al., 2013). The acceptable solution, often discussed by researchers would be to use non-food plant biomass for energy and to avoid competition for land (Robbins et al., 2012; Tanger et al., 2013).

Not only high yield but also appropriate composition of biomass of energy crops is important in the conversion processes. Biomass qualitative composition varies depending on plant species and even variety, specific growing conditions that can lead to an increase or depletion of different elements in certain growth stages (Vassilev et al., 2015). Many types of agricultural biomass contain undesirable chemical elements such as $\mathrm{S}$, $\mathrm{Cl}, \mathrm{Si}, \mathrm{P}, \mathrm{K}$ and $\mathrm{Na}$. As a result, appropriate combustionrelated biomass properties should be a deciding factor when choosing species for combustion (Fournel et al., 2015). Crop species, harvest timing and nitrogen rate most frequently affected the measured parameters and indicators of combustion (Kludze et al., 2013).

Most herbaceous plants positively respond to nitrogen fertilization (King et al., 2012; Muylle et al., 2015; Pocienè, Kadžiulienè, 2016; Tilvikiene et al., 2016). Lesser reliance on $\mathrm{N}$ fertilizer for plant biomass accumulation is an important agronomic and economic advantage. While analysing non-traditional energy crops, attention was drawn to Artemisia dubia, which distinguished itself among other energy crops by a rapid growth rate and high biomass productivity. In Nordic countries, this species has been little studied; and generally there is very little published data on $A$. dubia as an energy crop. Because little is known about the plant growth, development, biomass production and composition, the aim of the study was to investigate $A$. dubia growth, evaluate the productivity and chemical composition as influenced by management in the northern part of the temperate climate zone.

\section{Material and methods}

Experimentalsiteanddesign. Fieldandlaboratory experiments were carried out in Central Lithuania $\left(55^{\circ} 23^{\prime} 50^{\prime \prime} \mathrm{N}, 23^{\circ} 51^{\prime} 40^{\prime \prime} \mathrm{E}\right)$ at Institute of Agriculture, Lithuanian Research Centre for Agriculture. Artemisia dubia Wall. was grown on an Endocalcari-Epihypogleyic Cambisol (CMg-p-w-can). Soil characteristics: $\mathrm{pH}_{\mathrm{KCl}}$ 6.5, $\mathrm{K}_{2} \mathrm{O} 300 \mathrm{mg} \mathrm{kg}^{-1}$ and $\mathrm{P}_{2} \mathrm{O}_{5} 75 \mathrm{mg} \mathrm{kg}^{-1}$. The experiment was laid out in a randomized complete block design with four replicates. The year 2013 was A. dubia planting year and the first year of growing. The crop was planted by chopped roots, two roots per square meter. In the second year of growing, to ascertain the dynamics of plant height assessments were made once a month. Three treatments (not fertilized, fertilized with mineral nitrogen fertilizers 90 and $170 \mathrm{~kg} \mathrm{ha}^{-1} \mathrm{~N}$ ) were tested. Nitrogen fertilizer rate $90 \mathrm{~kg} \mathrm{ha}^{-1} \mathrm{~N}$ was applied once at the beginning of vegetation. The rate $170 \mathrm{~kg} \mathrm{ha}^{-1} \mathrm{~N}$ was split-applied: $90 \mathrm{~kg} \mathrm{ha}^{-1} \mathrm{~N}$ at the beginning of vegetation and $80 \mathrm{~kg} \mathrm{ha}^{-1}$ approximately a month after the first application. The fertilizers were used in the second and third years.

Estimation of biomass yield and composition. Dry matter (DM) yield was determined from the plots harvested at the beginning of December (after the first frosts). The study was conducted in 2013, 2014 and 2015. All of the collected biomass samples were weighed on site to measure the moisture content and dried for $12 \mathrm{~h}$ at $105^{\circ} \mathrm{C}$ in a laboratory to assess dry matter content.

For chemical analyses the samples were dried at $65 \pm 5^{\circ} \mathrm{C}$. Before analysing, the samples were ground by an ultra centrifugal mill ZM 200 ("Retch", Germany) using sieves of $2 \mathrm{~mm}$ mesh size. Prior to analyses, the samples prepared in the following way were assessed for dry matter. The content of nitrogen $(\mathrm{N})$, carbon $(\mathrm{C})$ and sulphur (S) was determined by dry combustion method in an oxygen atmosphere at $1145 \pm 5^{\circ} \mathrm{C}$ temperature according to the Dumas method (König, Fortman, 1996) using a fully automatic analyser Vario EL III ("Elementar", Germany). After the samples had been wet digested with sulphuric acid, the content of phosphorus (P) was determined by a spectrophotometric procedure at the wavelength of $430 \mathrm{~nm}$, and the content of potassium (K) was measured by atomo-absorciometric procedure after wet digestion with sulphuric acid. Chemical analyses were done at the Chemical Research Laboratory of the Institute of Agriculture, Lithuanian Research Centre for Agriculture and Forestry. The content of structural carbohydrates was calculated as differences: cellulose $($ Cell $)=\mathrm{ADF}-\mathrm{ADL}$, and hemicellulose $(\mathrm{HCell})=\mathrm{NDF}-\mathrm{ADF}$ (Hindrichsen et al., 2006). Heating value was measured with a bomb calorimeter C 200 (IKA, Germany) by the $25^{\circ} \mathrm{C}$ dynamic calorific test method and expressed as $\mathrm{MJ} \mathrm{kg}^{-1} \mathrm{DM}$.

Meteorological data. The weather conditions in 2013-2015 are presented in Table 1. Temperatures were consistently above multi-annual average from May through September of 2013. In 2014, temperatures from spring to autumn were also higher than average, except in June, when the temperature was $1.3^{\circ} \mathrm{C}$ lower than monthly average. Temperatures in early spring of 2015 were higher, while from May till August temperatures were lower and in August and September again higher than multi-annual average.

In the spring of 2013, establishment year of A. dubia, and at the beginning of summer precipitation was normal and in July even higher than average, but August was dry. In 2014, the rate of precipitation in spring and summer was close to the long-term average. However, August was rainy and autumn was dry. Below normal precipitation rate was in 2015, except for September. Overall, the growing seasons for biomass accumulation were changeable in terms of temperature and moisture conditions.

Statistical analysis. The obtained results were analysed using analysis of variance (ANOVA) and Fisher protected least significant difference (LSD) test $(p \leq 0.05)$.

\section{Results and discussion}

Artemisia dubia growth and biomass yield. The growing season in the first growing year of $A$. dubia was favourable and plant establishment was successful. The average plant height at the end of the growing season was $149 \mathrm{~cm}$. In a northern climate, the A. dubia lifecycle begins in May. In the second year of cultivation, in spring A. dubia resumed vegetation early and plant growth was rapid in the spring. The fast growth and the ability to accumulate biomass are important features of A. dubia distinguishing this plant from many traditional 
Table 1. The average monthly air temperature and precipitation

\begin{tabular}{|c|c|c|c|c|c|c|c|c|}
\hline \multirow{3}{*}{ Month } & \multicolumn{4}{|c|}{$\begin{array}{l}\text { Average air temperature } \\
{ }^{\circ} \mathrm{C} \\
\end{array}$} & \multicolumn{4}{|c|}{$\begin{array}{l}\text { Precipitation sum } \\
\mathrm{mm}\end{array}$} \\
\hline & \multicolumn{8}{|c|}{ Year } \\
\hline & 2013 & 2014 & 2015 & $\begin{array}{l}\text { multi-annual } \\
\text { average }\end{array}$ & 2013 & 2014 & 2015 & $\begin{array}{l}\text { multi-annual } \\
\text { average }\end{array}$ \\
\hline January & -7.0 & 5.7 & -0.6 & -4.7 & 35.5 & 36.6 & 72.6 & 31.1 \\
\hline February & -1.7 & 0.2 & 0.1 & -4.4 & 42.9 & 27.4 & 4.6 & 25.5 \\
\hline March & -4.8 & 4.8 & 4.4 & -0.7 & 8.6 & 31.4 & 48.7 & 28.1 \\
\hline April & 4.8 & 8.9 & 7.0 & 5.9 & 46.2 & 27.1 & 51.5 & 37.0 \\
\hline May & 16.0 & 13.0 & 11.4 & 12.3 & 49.6 & 76.8 & 50.4 & 52.3 \\
\hline June & 18.6 & 14.4 & 15.1 & 15.7 & 46.4 & 65.8 & 26.3 & 61.9 \\
\hline July & 18.5 & 20.0 & 17.1 & 17.8 & 104.3 & 69.1 & 57.6 & 75.3 \\
\hline August & 18.0 & 17.6 & 19.7 & 16.8 & 42.4 & 111.2 & 5.6 & 73.4 \\
\hline September & 12.6 & 13.3 & 14.0 & 12.1 & 77.8 & 21.7 & 66.0 & 51.3 \\
\hline October & 8.5 & 7.1 & 5.2 & 6.8 & 28.9 & 38.9 & 6.7 & 49.1 \\
\hline November & 4.8 & 2.7 & 4.7 & 1.9 & 46.7 & 31.9 & 71.3 & 45.0 \\
\hline December & 1.8 & -1.1 & 2.3 & -2.3 & 36.9 & 52.4 & 41.8 & 37.6 \\
\hline
\end{tabular}

grasses discussed as energy plants. At the beginning of June, the average height of plants was $145-155 \mathrm{~cm}$ (Fig. 1); however, the height was not affected by nitrogen treatment. Intensive plant growth continued until midsummer, but nitrogen fertilization had no apparent impact. Plant height increased until the second half of August and was greater than at the beginning of the summer, but no significant fertilization effect was observed. In the third year of cultivation plant growth was slower. At the

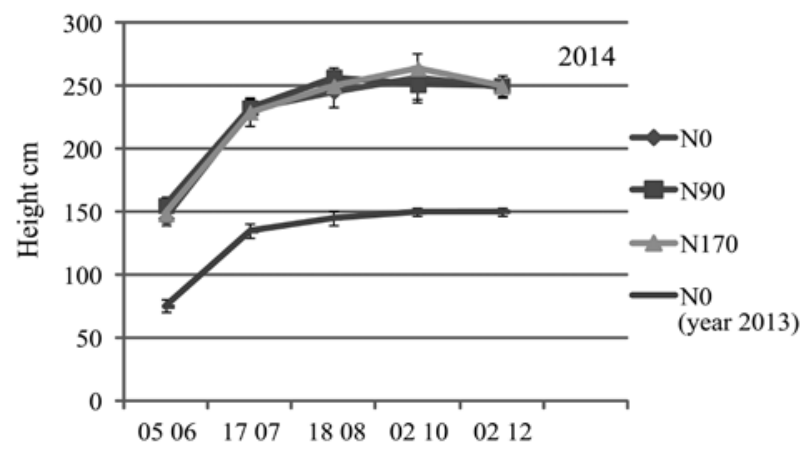

beginning of June, plant height was $114-126 \mathrm{~cm}$ and the maximum height was reached at the beginning of August, but it was smaller than in the second year. Differences in the plant height between years were caused by the effect of weather conditions. In the third year of cultivation, there was observed negligible influence of fertilization on plant height. Plants without nitrogen fertilization were shorter till the end of the growing season.

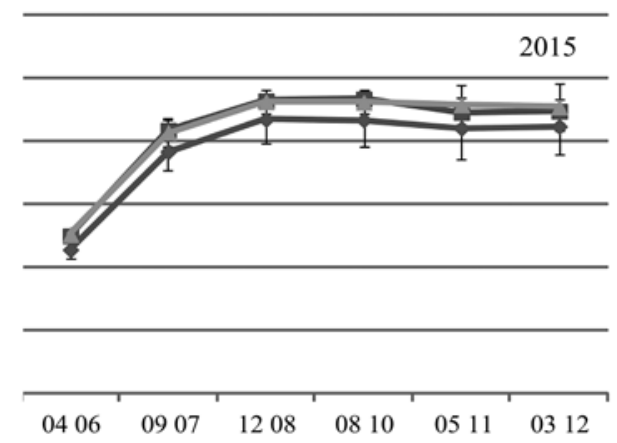

Figure 1. Dynamics of Artemisia dubia growth in the second and third year of cultivation

A. dubia biomass in early October (at the early end of vegetation season) was characterized by a high moisture content, around $70 \%$ with slight variations between fertilization treatments (Fig. 2). Subsequently, the moisture content decreases, as plant senescence begins (at the end of October). At the beginning of December, moisture content was nearly $35 \%$ in the second year of A.dubia cultivation. The differences between fertilization treatments were very small; however, the moisture content in fertilized treatments decreased more slowly. In the third year of cultivation, moisture content of $A$. dubia varied in a similar range as in the second year of cultivation and before harvest it was about $40 \%$ and fertilization treatments had no noticeable effect. From October to December, the moisture content of the crops consistently decreased and the decline indicated the need to delay the harvesting time, which would reduce transportation and storage costs. It is considered that the efficient combustion process requires moisture content of biomass to be below 50\% (McKendry, 2002).

Biomass grower or the user selecting a particular technological solution requires a wide range of knowledge, but above all, it is vital to know the yielding potential and optimal harvesting time. The aboveground biomass yield of $A$. dubia varied $\left(\mathrm{LSD}_{05}=4.6\right)$ from 4.64 to $5.07 \mathrm{tha}^{-1} \mathrm{DM}$ in the first year of cultivation and from 15.8 to $17.1 \mathrm{t} \mathrm{ha}^{-1} \mathrm{DM}$ in the second year (Fig. 3). Naturally, that the yield in the second year of $A$. dubia growing increased compared with the first year. The highest yield of $A$. dubia biomass was produced in the swards with mineral nitrogen fertilization at a rate of 170 $\mathrm{kg} \mathrm{ha}^{-1} \mathrm{~N}$; however, it was insignificantly higher compared to the yield reached not only at a rate of $90 \mathrm{~kg} \mathrm{ha}^{-1} \mathrm{~N}$ but without fertilization also. Our results indicate a high potential yield of $A$. dubia with and without nitrogen fertilization when compared, for example, with tall 

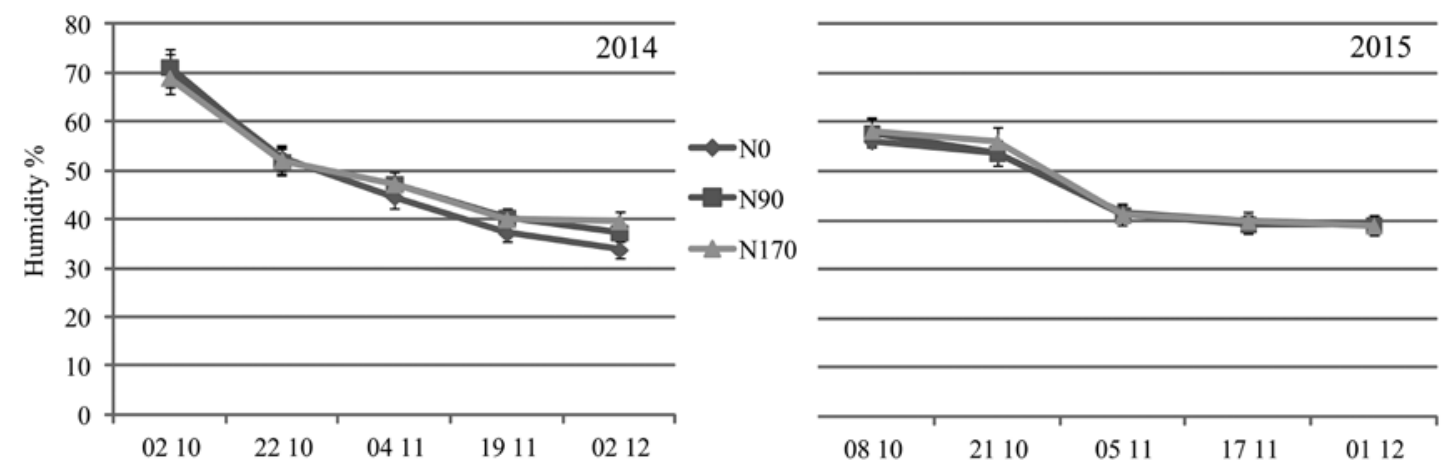

Figure 2. The change of moisture content of Artemisia dubia biomass during October-December

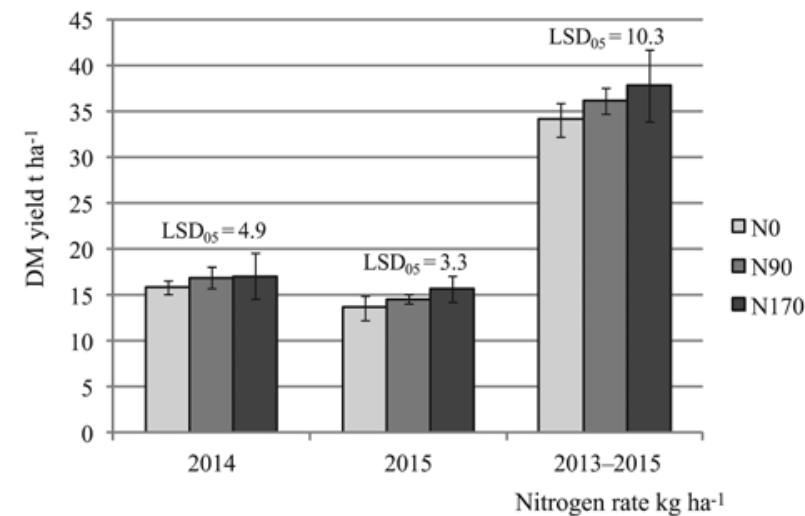

Figure 3. Biomass yield of Artemisia dubia from establishment year till the third growing year (20132015)

fescue or reed canary grass at the same location (Pociene, Kadžiulienè, 2016) or investigated related species A. vulgaris (Siaudinis et al., 2015), or intensively cropped maize (Povilaitis et al., 2016). More studies were carried out on reed canary grass in Northern European countries, the estimated dry matter yields ranged between $5-10$ tha $^{-1}$ depending on management (Kukk et al., 2011; Tilvikiene et al., 2016). In the present study, A. dubia yielded more biomass than the above-mentioned crops. This positive feature of the plant has already been observed in previous studies (Kryževičienè et al., 2010).

The aboveground biomass yield of Artemisia dubia in the third year of cultivation was lower than that in the second year. In both years, nitrogen fertilization did not have significant influence on the biomass yield of A. dubia (Fig. 3). As the biomass yield even without $\mathrm{N}$ fertilization was relatively higher than that of previously evaluated traditional energy grasses, A. dubia was found to be a potential energy crop. However, it is not known how long A. dubia can be grown and produce high biomass yield in the same site without being reestablished. It has already been documented that this crop can perform well for at least 4-5 years (Kadžiulienè et al., 2013). It is important to assess the yields of a few years because the plants are exposed not only to the management measures, but also the soil, weather and crop conditions (Kludze etal., 2013; López-Bellido et al., 2014). Although A. dubia does not need nitrogen fertilization to achieve high yields, $\mathrm{N}$ fertilization might influence biomass quality.

The analysis of biomass characteristics relevant for combustion. For any energy conversion system biochemical and elemental properties of biomass are relevant (Nhuchhen, 2016) and end-use efficiency could be affected. The concentration of fibre components (cellulose, hemicellulose and lignin) in the biomass is important for combustion. The results show that $\mathrm{N}$ treatment had effect on the fibre composition during both years (Table 2); however, the results are still inconsistent. Cellulose content was the highest in the second year of A. dubia growth without nitrogen fertilization, while in the third year of growth it was the lowest. Even though some differences were detected among cellulose and hemicellulose, there was no consistent pattern across years as a result of the $\mathrm{N}$ treatments. In the second year of $A$. dubia growing, lignin content in the biomass was significantly highest when nitrogen fertilization at a rate of $170 \mathrm{~kg} \mathrm{ha}^{-1}$ had been used. Significantly higher lignin content was accumulated in A. dubia fertilized at a rate of $90 \mathrm{~kg} \mathrm{ha}^{-1} \mathrm{~N}$ compared to treatment without fertilization.

Table 2. Cellulose, hemicellulose and lignin content in Artemisia dubia biomass as influenced by nitrogen fertilization

\begin{tabular}{|c|c|c|c|c|c|c|}
\hline \multirow{3}{*}{$\begin{array}{l}\text { N-fertilizer rate } \\
\mathrm{kg} \mathrm{ha}^{-1}\end{array}$} & \multicolumn{6}{|c|}{ Fibre components $\mathrm{g} \mathrm{kg}^{-1} \mathrm{DM}$} \\
\hline & \multicolumn{2}{|c|}{ cellulose } & \multicolumn{2}{|c|}{ hemicellulose } & \multicolumn{2}{|c|}{ lignin } \\
\hline & 2014 & 2015 & 2014 & 2015 & 2014 & 2015 \\
\hline 0 & 538.8 & 483.0 & 87.3 & 55.9 & 165.4 & 156.2 \\
\hline 90 & 529.0 & 502.4 & 75.5 & 78.4 & 170.2 & 153.3 \\
\hline 170 & 519.1 & 498.1 & 72.7 & 88.4 & 177.0 & 152.6 \\
\hline $\mathrm{LSD}_{05}$ & 66.5 & 46.9 & 17.8 & 12.6 & 3.7 & 1.3 \\
\hline
\end{tabular}


However, the same effect was not obtained in the third year of $A$. dubia cultivation and nitrogen treatment did not alter its content. Lignin content is important for combustion (McKendry, 2002), although part of lignin in the biomass was significantly lower than that of cellulose, lignin depending on its content, or more precisely on its ratio with cellulose in combustion process may not have the same influence on the properties. Thus, the low lignin content fibres are those having the best fire behaviour; however, heating value of a lignocellulosic fuel is a function of its lignin content and it increases with increasing lignin content in biomass (Demirbas, 2004).

Many chemical elements of biomass are potential contributors to pollution during combustion process (Williams et al., 2012). The biomass of most agricultural crops can contain relatively high levels of $\mathrm{N}$, $\mathrm{Cl}$ and $\mathrm{S}$, which can contribute to high emissions of $\mathrm{NO}_{x}$, $\mathrm{HCl}$ and $\mathrm{SO}_{2}$ and boiler corrosion during combustion
(Obernberger et al., 2006; Fournel et al., 2015). Nitrogen fertilization in most cases is required for improvement of biomass productivity; however, it may have a negative influence on the quality parameters of the biomass and combustion process (Kludze et al., 2013). The analysis of chemical elements in the biomass of A. dubia in the second and third year of cultivation showed that they varied depending on fertilization (Table 3); however, the greatest differences were not obtained either for $\mathrm{C}, \mathrm{S}$, $\mathrm{P}$ or $\mathrm{K}$ content. Nitrogen concentration in the biomass was influenced by $\mathrm{N}$ rates, but only $170 \mathrm{~kg} \mathrm{ha}^{-1} \mathrm{~N}$ had significant effect on nitrogen content in $A$. dubia biomass in both years of growing. Even not very high from the agronomic point of view $\mathrm{N}$ fertilization at $80 \mathrm{~kg} \mathrm{ha}^{-1}$ tended to increase fouling and slagging; therefore some results suggest that combustion quality could be improved by agronomic management consisting of little or no nitrogen fertilization (Kludze et al., 2013).

Table 3. Chemical elements and heating value of the Artemisia dubia biomass

\begin{tabular}{|c|c|c|c|c|c|c|c|}
\hline \multirow{2}{*}{$\begin{array}{c}\text { N-fertilizer rate } \\
\mathrm{kg} \mathrm{ha}^{-1}\end{array}$} & \multicolumn{6}{|c|}{$\%$ in $\mathrm{DM}$} & \multirow{2}{*}{$\begin{array}{l}\text { Heating value } \\
\qquad \mathrm{MJ} \mathrm{kg}^{-1}\end{array}$} \\
\hline & $\mathrm{N}$ & $\mathrm{S}$ & $\mathrm{C}$ & $\mathrm{P}$ & $\mathrm{K}$ & Ash & \\
\hline \multicolumn{8}{|c|}{2014} \\
\hline 0 & 0.457 & 0,087 & 49.11 & 0.052 & 0.526 & 3.20 & - \\
\hline 90 & 0.485 & 0.080 & 48.81 & 0.053 & 0.563 & 3.27 & - \\
\hline 170 & 0.597 & 0.080 & 48.81 & 0.071 & 0.593 & 3.30 & - \\
\hline $\mathrm{LSD}_{05}$ & 0.028 & 0.015 & 0.585 & 0.026 & 0.188 & 0.712 & - \\
\hline \multicolumn{8}{|c|}{2015} \\
\hline 0 & 0.349 & 0.091 & 49.3 & 0.040 & 0.459 & 3.57 & $18.50 \pm 0.662$ \\
\hline 90 & 0.476 & 0.077 & 49.3 & 0.036 & 0.391 & 3.11 & $18.53 \pm 0.116$ \\
\hline 170 & 0.559 & 0.075 & 49.7 & 0.038 & 0.394 & 3.47 & $18.78 \pm 0.185$ \\
\hline $\mathrm{LSD}_{05}$ & 0.161 & 0.022 & 0.902 & 0.033 & 0.142 & 0.339 & \\
\hline
\end{tabular}

Application of nitrogen fertilizers did not have significant effect on ash concentration in the biomass in the second and third year of $A$. dubia cultivation (Table 3). Our scarce research on $A$. dubia suggests that this plant could be a useful energy plant for combustion. Nitrogen fertilization does not cause such a major change in the elemental composition of biomass, and as previous studies (Kadžiulienè et al., 2013) have shown ash content was considerably lower than in other herbaceous plants. Such a low ash value is important because, as noted by other researchers, biomass from agricultural crops is usually characterised by high ash content (Obernberger et al., 2006). The ash content has the greatest role in differentiating biomass energy properties and fuel energy content between species and between varieties (Tao et al., 2012). Through knowledge of the chemical composition and physical properties of ash, it is possible to predict the tendency to form deposits in the boiler components, as well as their potential to cause corrosion, erosion and abrasion (Nunes et al., 2016). The high ash content in biomass reduces the energy available in the material, and thus reduces the conversion efficiency; therefore efficient energy in combustion could be expected from $A$. dubia biomass with low content of ash.

Heating value is considered to be an important fuel parameter in the combustion chain, therefore it is necessary to analyse it (Nhuchhen, Salam, 2012), especially of less known crops. Heating value of $A$. dubia with fertilization (Table 3 ) or without differed negligibly and this value is in good agreement reported for other crops (Jasinskas et al., 2008; Siaudinis et al., 2015; Povilaitis et al., 2016).

Many different crops could be used for energy purposes; however, the cultivation of perennial crops as A. dubia with lower nutrient demand and other inputs provides advantages in choosing plants to use.

\section{Conclusions}

1. The ability to accumulate high biomass yield during the first three growing years is an important feature of Artemisia dubia Wall. The moisture content of A. dubia biomass decreased consistently from October to December and reached the optimal level for combustion at the end of November and beginning of December. In the second and third growing year of $A$. dubia, the annual dry matter yield ranged from 15.8 to $17.1 \mathrm{t} \mathrm{ha}^{-1}$ and the biomass yield of not fertilized swards was as high as that of swards fertilized with mineral nitrogen.

2. Results indicated that chemical characteristics of $A$. dubia biomass are suitable for combustion. The most 
marked response to nitrogen fertilization was observed in nitrogen content and lignin in the biomass. The biomass of $A$. dubia exhibited a relatively small ash content, which is an advantage when burning the biomass and showed higher heating value, although application of nitrogen fertilizers did not improve these characteristics.

3 . The relatively low ash content and a heating value of $18.5 \mathrm{MJ} \mathrm{kg}^{-1}$ even without nitrogen fertilization makes $A$. dubia a promising energy crop in the northern part of a temperate climate zone. Nevertheless, further investigation and analyses on $A$. dubia are needed to validate biomass productivity, quality and energy potential in senescent crops.

\section{Acknowledgements}

This research was funded by a grant (No. MIP041/2014) from the Research Council of Lithuania.

Received 28072016

Accepted 27032017

\section{References}

Corton J., Donnison I. S., Patel M., Bühle L., Hodgson E., Wachendorf M., Bridgwater A., Allison G., Fraser M. D. 2016. Expanding the biomass resource: sustainable oil production via fast pyrolysis of low input high diversity biomass and the potential integration of thermochemical and biological conversion routes. Applied Energy, 177: 852-862 https://doi.org/10.1016/j.apenergy.2016.05.088

Dauber J., Jones M. B., Stout J.C. 2010. The impact of biomass crop cultivation on temperate biodiversity. GCB Bioenergy, 2: $289-309$ https://doi.org/10.1111/j.1757-1707.2010.01058.x

Demirbas A. 2004. Combustion characteristics of different biomass fuels. Progress in Energy and Combustion Science, 30: 219-230 https://doi.org/10.1016/j.pecs.2003.10.004

Fournel S., Palacios J. H., Morissette R., Villeneuve J., Godbout S., Heitz M., Savoie P. 2015. Influence of biomass properties on technical and environmental performance of a multi-fuel boiler during on-farm combustion of energy crops. Applied Energy, 141: 247-259 https://doi.org/10.1016/j.apenergy.2014.12.022

Heinsoo K., Hein K., Melts I., Holm B., Ivask M. 2011. Reed canary grass yield and fuel quality in Estonian farmers' fields. Biomass and Bioenergy, 35: 617-625 https://doi.org/10.1016/j.biombioe.2010.10.022

Hindrichsen I. K., Wettstein H. R., Machmüller A., Bach Knudsen K. E., Madsen J., Kreuzer M. 2006. Digestive and metabolic utilisation of dairy cows supplemented with concentrates characterised by different carbohydrates. Animal Feed Science and Technology, 126: 43-61 https://doi.org/10.1016/j.anifeedsci.2005.06.004

Jasinskas A., Żaltauskas A., Kryževičienè A. 2008. The investigation of growing and using of tall perennial grasses as energy crops. Biomass and Bioenergy, 32 (11): 981-987 https://doi.org/10.1016/j.biombioe.2008.01.025

Kadžiulienè Ž., Šarūnaitė L., Tilvikienė V., Šlepetys J., Dabkevičius Z. 2013. Biomass of grasses and other herbaceous plants for bioenergy use. Revitalising Grasslands to Sustain our Communities: proceedings $22^{\text {nd }}$ international grassland congress. Australia, p. 1782-1785
King C., McEniry J., Richardson M., O’Kiely P. 2012. Yield and chemical composition of five common grassland species in response to nitrogen fertiliser application and phenological growth stage. Acta Agricultirae Scandinavica, Section B: Soil and Plant Science, 62 (7): 644-658 https://doi.org/10.1080/09064710.2012.687055

Kludze H., Deen B., Dutta A. 2013. Impact of agronomic treatments on fuel characteristics of herbaceous biomass for combustion. Fuel Processing Technology, 109: 96-102 https://doi.org/10.1016/j.fuproc.2012.09.043

König N., Fortmann H. 1996. Probenvorbereitungs-, Untersuchungs- und Elementbestimmungs-Methoden des Umweltanalytik-Labors der Niedersächsischen Forstlichen Versuchsanstalt, 1-4, Berichte des Forschungszentrums Waldokosysteme, Reihe B, University of Gottingen, Germany, B46-B49 (in German)

Kryževičienė A., Šarūnaitė L., Stukonis V., Dabkevičius Z. 2010. Assessment of perennial mugwort (Artemisia vulgaris L. ir Artemisia dubia Wall.) potential for biofuel production. Žemès ūkio mokslai, 17 (1-2): 32-40

Kukk L., Roostalu H., Suuster E., Rossner H., Shanskiy M., Astover A. 2011. Reed canary grass biomass yield and energy use efficiency in Northern European pedoclimatic conditions. Biomass and Bioenergy, 35: 4407-4416 https://doi.org/10.1016/j.biombioe.2011.08.018

Laurent A., Pelzer E., Loyce C., Makowski D. 2015. Ranking yields of energy crops: a meta-analysis using direct and indirect comparisons. Renewable and Sustainable Energy Reviews, 46: 41-50 https://doi.org/10.1016/j.rser.2015.02.023

López-Bellido L., Wery J., López-Bellido R. J. 2014. Energy crops: prospects in the context of sustainable agriculture. European Journal of Agronomy, 60: 1-12 https://doi.org/10.1016/j.eja.2014.07.001

Lord R. A. 2015. Reed canary grass (Phalaris arundinacea) outperforms Miscanthus or willow on marginal soils, brownfield and non-agricultural sites for local, sustainable energy crop production. Biomass and Bioenergy, 78: $110-125$ https://doi.org/10.1016/j.biombioe.2015.04.015

McKendry P. 2002. Energy production from biomass (part 2): conversion technologies. Bioresource Technology, 83 (1): 47-54 https://doi.org/10.1016/S0960-8524(01)00119-5

Muylle H., Van Hulle S., DeVliegher A., Baert J., Van Bockstaele E., Roldán-Ruiza I. 2015. Yield and energy balance of annual and perennial lignocellulosic crops for bio-refinery use: a 4-year field experiment in Belgium. European Journal of Agronomy, 63: 62-70 https://doi.org/10.1016/j.eja.2014.11.001

Naik S. N., Goud V. V., Rout P. K., Dalai A. K. 2010. Production of first and second generation biofuels: a comprehensive review. Renewable and Sustainable Energy Reviews, 14 (2): 578-597 https://doi.org/10.1016/j.rser.2009.10.003

Nhuchhen D. R. 2016. Prediction of carbon, hydrogen, and oxygen compositions of raw and torrefied biomass using proximate analysis. Fuel, 180: 348-356 https://doi.org/10.1016/j.fuel.2016.04.058

Nhuchhen D. R., Salam P. A. 2012. Estimation of higher heating value of biomass from proximate analysis: a new approach. Fuel, 99: 55-63 https://doi.org/10.1016/j.fuel.2012.04.015 
Nunes L. J. R., Matias J. C. O., Catalão J. P. S. 2016. Biomass combustion systems: a review on the physical and chemical properties of the ashes. Renewable and Sustainable Energy Reviews, 53: 235-242

https://doi.org/10.1016/j.rser.2015.08.053

Obernberger I., Brunner T., Bärnthaler G. 2006. Chemical properties of solid biofuels - significance and impact. Biomass and Bioenergy, 30: 973-982 https://doi.org/10.1016/j.biombioe.2006.06.011

Palmer I. E., Gehl R. J., Ranney T. G., Touchell D., George N. 2014. Biomass yield, nitrogen response, and nutrient uptake of perennial bioenergy grasses in North Carolina. Biomass and Bioenergy, 63: 218-228 https://doi.org/10.1016/j.biombioe.2014.02.016

Pedroli B., Elbersen B., Frederiksen P., Grandin U., Heikkilä R., Henning Krogh P., Izakovičová Z., Johansen A., Meiresonne L., Spijker J. 2013. Is energy cropping in Europe compatible with biodiversity? - Opportunities and threats to biodiversity from landbased production of biomass for bioenergy purposes. Biomass and Bioenergy, 55: $73-86$ https://doi.org/10.1016/j.biombioe.2012.09.054

Pocienė L., Kadžiulienè Ž. 2016. Biomass yield and fibre components in reed canary grass and tall fescue grown as feedstock for combustion. Zemdirbyste-Agriculture, 103 (3): $297-304$ https://doi.org/10.13080/z-a.2016.103.038

Povilaitis V., Šlepetienė A., Šlepetys J., Lazauskas S., Tilvikienė V., Amalevičiūtė K., Feizienė D., Feiza V., Liaudanskienė I., Cesevičienè J., Kadžiulienė Ž., Kukujevas A. 2016. The productivity and energy potential of alfalfa, fodder galega and maize plants under the conditions of the nemoral zone. Acta Agriculturae Scandinavica, Section B: Soil and Plant Science, 66 (3): 259-266 https://doi.org/10.1080/09064710.2015.1093651

Prochnow A., Heiermann M., Plöchl M., Amon T., Hobbs P. J. 2009. Bioenergy from permanent grassland - a review: 2. Combustion. Bioresource Technology, 100 (21): 4945-4954 https://doi.org/10.1016/j.biortech.2009.05.069

Robbins M. P., Evans G., Valentine J., Donnison I. S., Allison G. G. 2012. New opportunities for the exploitation of energy crops by thermochemical conversion in Northern Europe and the UK. Progress in Energy and Combustion Science, 38: 138-155 https://doi.org/10.1016/j.pecs.2011.08.001

Scarlat N., Dallemand J.-F., Ferrario M.-F., Nita V. 2015. The role of biomass and bioenergy in a future bioeconomy: policies and facts. Environmental Development, 15: 3-34 https://doi.org/10.1016/j.envdev.2015.03.006

Searle S. Y., Malins C. J. 2014. Will energy crop yields meet expectations? Biomass and Bioenergy, 65: 3-12 https://doi.org/10.1016/j.biombioe.2014.01.001

Seay J. R., Badurdeen F. F. 2014. Current trends and directions in achieving sustainability in the biofuel and bioenergy supply chain. Current Opinion in Chemical Engineering, 6: $55-60$ https://doi.org/10.1016/j.coche.2014.09.006

Siaudinis G., Jasinskas A., Sarauskis E., Steponavicius D., Karcauskiene D., Liaudanskiene I. 2015. The assessment of Virginia mallow (Sida hermaphrodita Rusby) and cup plant (Silphium perfoliatum L.) productivity, physicomechanical properties and energy expenses. Energy, 93: 606-612

https://doi.org/10.1016/j.energy.2015.09.065
Skenhall S. A., Berndes G., Woods J. 2013. Integration of bioenergy systems into UK agriculture - new options for management of nitrogen flows. Biomass and Bioenergy, 54: $219-226$

https://doi.org/10.1016/j.biombioe.2013.04.002

Tanger P., Field J. L., Jahn C. E., DeFoort M. W., Leach J. E. 2013. Biomass for thermochemical conversion: targets and challenges. Frontiers in Plant Science, 4: 1-20 https://doi.org/10.3389/fpls.2013.00218

Tao G., Lestander T. A., Geladi P., Xiong S. 2012. Biomass properties in association with plant species and assortments I: a synthesis based on literature data of energy properties. Renewable and Sustainable Energy Reviews, 16 (5): $3481-3506$ https://doi.org/10.1016/j.rser.2012.02.039

Tilman D., Socolow R., Foley J. A., Hill J., Larson E., Lynd L., Pacala S., Reilly J., Searhinger T., Somerville C., Williams R. 2009. Beneficial biofuels - the food, energy, and environment trilemma. Science, 325: 270-271 https://doi.org/10.1126/science. 1177970

Tilvikiene V., Kadziuliene Z., Dabkevicius Z., Venslauskas K., Navickas K. 2016. Feasibility of tall fescue, cocksfoot and reed canary grass for anaerobic digestion: analysis of productivity and energy potential. Industrial Crops and Products, 84: 87-96 https://doi.org/10.1016/j.indcrop.2016.01.033

Tonn B., Thumm U., Claupein W. 2010. Semi-natural grassland biomass for combustion: influence of botanical composition, harvest date and site conditions on fuel composition. Grass and Forage Science, 65: 383-397 https://doi.org/10.1111/j.1365-2494.2010.00758.x

Van Meerbeek K., Appels L., Dewil R., Van Beek J., Bellings L., Liebert K., Muys B., Hermy M. 2015. Energy potential for combustion and anaerobic digestion of biomass from lowinput high-diversity systems in conservation areas. GCB Bioenergy, 7: 888-898 https://doi.org/10.1111/gcbb.12208

Vassilev S. V., Vassileva C. G., Vassilev V. S. 2015. Advantages and disadvantages of composition and properties of biomass in comparison with coal: an overview. Fuel, 158: $330-350$

https://doi.org/10.1016/j.fuel.2015.05.050

Von Cossel M., Lewandowski I. 2016. Perennial wild plant mixtures for biomass production: impact of species composition dynamics on yield performance over a fiveyear cultivation period in southwest Germany. European Journal of Agronomy, 79: 74-89 https://doi.org/10.1016/j.eja.2016.05.006

Williams A., Jones J. M., Ma L., Pourkashanian M. 2012. Pollutants from the combustion of solid biomass fuels. Progress in Energy and Combustion Science, 38: 113-137 https://doi.org/10.1016/j.pecs.2011.10.001

Yilmaz S., Selim H. 2013. A review on the methods for biomass to energy conversion systems design. Renewable and Sustainable Energy Reviews, 25: 420-430 https://doi.org/10.1016/j.rser.2013.05.015 
ISSN 1392-3196 / e-ISSN 2335-8947

Zemdirbyste-Agriculture, vol. 104, No. 2 (2017), p. 99-106

DOI 10.13080/z-a.2017.104.013

\title{
Artemisia dubia augimas, derlius ir biomasės tinkamumas deginti
}

\author{
Ž. Kadžiuliene் ${ }^{1}$, V. Tilvikiené ${ }^{1}$, I. Liaudanskienè $\dot{e}^{1}$ L. Pocienè \\ Ž. Černiauskiené ${ }^{2}$, E. Zvicevicius ${ }^{2}$, A. Raila ${ }^{2}$ \\ ${ }^{1}$ Lietuvos agrarinių ir miškų mokslų centro Žemdirbystès institutas \\ ${ }^{2}$ Aleksandro Stulginskio universitetas
}

\section{Santrauka}

Daugelyje šiauresnių šalių padidèjo susidomejjimas žemès ūkio augalų biomasès naudojimu energijos tikslais, o tvariam naudojimui reikalingi kuo didesnio derlingumo ir tinkamos kokybès nauji augalai. Tyrimo tikslas - nustatyti Artemisia dubia Wall. biomasès derlių auginant vidutinio klimato sąlygomis ir biomasès savybes deginant. Augalai auginti giliau karbonatingame sekliai glejiškame rudžemyje (RDg8-k2) netręšiant ir tręšiant mineralinėmis azoto trąšomis 90 ir $170 \mathrm{~kg} \mathrm{ha}^{-1} \mathrm{~N}$. Augalų augimas, derlius ir deginimui svarbios biomasès savybès vertinta antraisiais ir trečiaisiais augalų auginimo metais. Azoto trąšos šiek tiek didino augalų aukštį ir biomasės kaupimą, tačiau drègmès kiekis biomasėje mažèjo lèčiau. Tręšiant azotu augalų biomasès antrujų ar trečiųjų auginimo metų metinio derliaus esminio padidejjimo negauta, tačiau ir be tręšimo azotu gautas 15,8 iki 17,1 $\mathrm{t} \mathrm{ha}^{-1}$ sausųjų medžiagų derlius lenkia vidutinius kitų augalų biomasès derlius. Tręšimas azotu esmingai didino azoto ir lignino kiekius biomasėje. Nepriklausomai nuo tręšimo, degimo proceso svarbių cheminių elementų anglies ir sieros vertès biomasèje kito nežymiai. Augalų netręšiant gautas gana nedidelis kiekis pelenų, o šilumingumas siekė $18,5 \mathrm{MJ} \mathrm{kg}^{-1}$. Siekiant išsamiau ịvertinti daugiamečių kiečių biomasės derlių bei kokybinès sudėties vertes ir tręšimo įtaką, reikia papildomų tyrimų.

Reikšminiai žodžiai: energiniai augalai, ląstelienos komponentai, pelenai, tręšimas azotu, šilumingumas. 